\title{
Preparing the Implementation of Merdeka Belajar - Kampus Merdeka Policy in Higher Education Institutions
}

\author{
Eko Purwanti ${ }^{1, *}$ \\ ${ }^{1}$ Universitas Muhammadiyah Yogyakarta, Yogyakarta, Indonesia \\ *Email: ekopurwanti@umy.ac.id
}

\begin{abstract}
The Indonesian Minister of Education and Culture has recently issued the policy of 'Merdeka Belajar- Kampus Merdeka' $(M B K M)$ or Freedom to Learn-Independent Campus. While the Freedom to Learn policy is focused more on basic and secondary levels of education, the latter aims to regulate higher education levels. There are four important points of MBKM policy; 1) automatic re-accreditation for study program, 2) students' rights to study for three semesters outside study programs, 3) autonomy to establish study programs for qualified universities, and 4) freedom for State Universities to become Legal Corporation. These four programs are basically intended to give freedom for Higher Education Institutions (HEIs) to be more autonomous, independent, less bureaucratic, and innovative. Of these four programs of MBKM policy, students' rights to study outside their study program for at least three semesters is quite interesting as it is meant to support 'link and match' program between the HEIs and their users. In the long run, this program is potential to increase students' employability and employment rates of graduates. However, as this policy is relatively new; and therefore, its implementation is still in scarcity, it could have been mistakenly addressed in HEIs. In addition, this policy is perhaps skeptically responded by some educators as it is not uncommon thing in Indonesia that every change in Minister of Education and Culture is resulted in the curriculum change as well. Therefore, while some universities have responded positively and start making actions regarding the policy, others are still debating, waiting for other universities to make actions regarding the new policy. Regardless the pros and cons opinions about the MBKM policy, the ideas of the policy itself remain obvious, supporting graduates' employability and linking them to the job market. Thus, MBKM policy can be a good solution to minimize the number of unemployment rate in Indonesia which reached 6.88 million people in February 2020, increasing up 60 thousand people compared to that in the previous year. This paper discusses the preparation in implementing the policy of MBKM in tertiary levels of education, especially in relation to graduates' employability.
\end{abstract}

Keywords: Merdeka Belajar, Kampus Merdeka, Graduates’ Employability, Link and Match, Employment Rate

\section{INTRODUCTION}

Education is regarded as an important aspect of people's life in the world, including in Indonesia. Good education is often associated with good quality of life, especially in terms of wealth [1]. Ten years later, Wolla and Sullivan [2] mentioned that education is often associated to investment in human capital, meaning that people with higher level of education have better income. This results in many people eager to complete their study until the highest level of education because their degree can be regarded as a ticket for their success or better future. However, a statistical data from National Statistics (BPS) reported that the number of unemployment rate increases up to 60 thousand people compared to that in the previous year in February 2020 [3]. Thus, the total number of unemployment rate in Indonesia is 6.88 million people. It means that of 100 people of Indonesia, five people are unemployed.

Higher Education Institutions (HEIs) become the key important factors responsible for producing qualified graduates [4] Law No 12 Year 2012 on Higher Education System states that one of the objectives that should be fulfilled in HEIs is to produce graduates who master Science and/or Technology to meet national interests and increase national competitiveness [5]. This implies that HEIs become the place in which students learn both hard 
skills and soft skills so that after they have completed their study, they are ready to involve in the work field. Unfortunately, however, many university graduates struggles to fulfil industrial or company's demand due to several factors, such as lack of competencies, lack of experiences, lack of attributes needed in the job field due to lack of partnership between the university and the users [6], [7], [8]. These phenomena indicate low graduates' employability which eventually results in low employment rates of graduates. Thus, enhancing employability should be carried out seriously. Improving employability means, then, taking seriously many of the long-established higher education targets and developing structures that are likely to help most students make better, more compelling claims for achievement in their regard [9].

Employability which also means a collection of students' experiences and attributes [10] are developed through students' learning in the university. The government in Indonesia still faces the problem of high educated unemployment. This is reflected in the level of open unemployment (TPT) university graduates with a range of S1 to S3 education that reaches 737,000 people [3]. Therefore, HEIs are demanded to ensure that their graduates are properly employed based on their expertise after completing their study and failing to do so is potential to increase unemployment rates in Indonesia. In fact, increasing employability, in the Indonesian HEIs context, has been formulated by the Ministry of Education and Culture through the policy of 'Merdeka Belajar- Kampus Merdeka (MBKM)' or Freedom to Learn - Independent Campus.

The policy of MBKM has been launched by the Indonesian Minister of Education and Culture in February 2020. The main objective of the MBKM is to give freedom to HEIs in order to be more autonomous, independent, less bureaucratic, and innovative which eventually result in students' highly qualified graduates [11[. This outcome is indeed very important in that it provides students' graduates with opportunity to be more competitive in global job market. As this MBKM is regarded as an initial stage of HEIs freedom, the Indonesian Minister of Education and Culture, Nadiem Makarim, suggested that the quality be ignored, rather it focused more on the agent of the education outcomes; the students [12]. In addition, as this policy is relatively new in Indonesia, many people are debating and giving criticism about its implementation, while on the other hand, many others welcome and support the policy enthusiastically [13]. These controversial issues are interesting to point out, and therefore the study aims to investigate the MBKM policy, especially its implementation in HEIs.

\subsection{Merdeka Belajar-Kampus Merdeka (MBKM) Policy}

Employability which is simply defined as a collection of students' experiences and attributes [10] has become one of important indicators to assess the credibility of Higher Education Institutions (HEIs). Students' employability is developed through students' learning in the university. A university is demanded to ensure that its graduates are properly employed based on their expertise after completing their study, and therefore an outcome based (OBE) curriculum are now widely implemented in HEIs [14].

However, numerous studies have revealed that university graduates have problems in finding appropriate jobs upon their study accomplishment [15], [16], [17]. The statistical data from National Statistics (BPS) reported that the number of unemployment rate increases up to 60 thousand people compared to that in the previous year in February 2020. Thus, the total number of unemployment rate in Indonesia is 6.88 million people. It means that of 100 people of Indonesia, five people are unemployed. Various articles and research also reveal that many university' graduates work in labor fields and get low payment [18], [19]. Finally, there is a new trend among university' graduates to pursue higher studies to avoid unemployment. A study conducted by Yang [20] reported that Humanities and Social Science (HSS) students of the comprehensive state university are more likely to pursue graduate studies in response to a high risk of unemployment. How do such things happen? The answer is perhaps because there is scarcity in 'link and match' between university graduates and the users. In other words, university graduates find it hard to fulfil the users' demand or students are not ready to be involved in the work field once they accomplish their study [18]. It becomes common knowledge that students merely master the theory but lack of practices. This situation results in low rates of employment, and therefore it affects Indonesian unemployment rate. In this case, the government should interfere with certain policy to increase graduate employability.

Increasing employability, in the context of HEIs in Indonesia, has been formulated by the Ministry of Education and Culture through the concept of 'Merdeka Belajar-Kampus Merdeka’ MBKM since January 2020. The main idea of MBKM Policy is basically the freedom of autonomy, independence, accelerated bureaucracy, and innovation in higher education [11]. These reasons are also stated by Nadiem Makarim during the Independent Policy launching in January, 2020 [20]. The first reason is to encourage HEIs to be more adaptive because Higher Education Institutions have the potential to produce human capital needed by the users. In addition, the second reason is to accelerate innovation in the areas of three pillars of higher education such as curriculum innovation, community service innovation, and research innovation. The third reason is to promote new paradigm that education become responsibility of not only HEIs but also industry, associations, and other elements of society. Finally, the fourth reason aims to train university students to be more adaptive, meaning that the students should be ready to leave their comfort zone extending learning outside their study program or 
off campus such as internships, teaching in the region, research collaboration, student exchanges, and others according to their own interests.

These ideas are reflected in four programs of Independent Campus policy, comprising 1) automatic reaccreditation for study program, 2) freedom for State Universities to become Legal Corporation, 3) autonomy to establish study programs for qualified universities, and 4) students' rights to study for three semesters outside study programs [11]. The latter gives rights for students the freedom to take subjects outside the study program for three semesters. These MBKM programs are expected to challenge HEIs to produce graduates who excels and updates with the development of science and technology in order to fulfil the demands of the business and industrial world. Focusing on student-centered learning, the students' rights to take subject three semesters outside the study program is meant to improve graduate competencies, both soft skills and hard skills by doing various activities. Various forms of the students' learning activities include 1) conducting internships / work practices in industry or other workplaces, 2) carrying out community service projects in villages, 3) teaching in education units, 4) participating in student exchanges, 5) conducting research, 6) conducting entrepreneurial activities, 7) making studies / independent projects, and 8) joining the humanitarian program. All of these activities must be supervised by a supervising lecturer.

Students' learning outside study program can be regarded as experiential learning programs aiming at facilitating students in developing their potential according to their passion and talent. Thus, this program is expected to provide authentic and contextual experience which finally improve students' competences needed in the job field. In order to meet the demands, and to prepare students in the world of work, HEIs are required to be able to design and implement innovative learning processes so that students can obtain achievements learning includes aspects of attitude, knowledge, and skills optimally. Clarke [22] mentioned that some of the strategies done by the HEIs to build and enhance graduate employability are integrating skills needed by the users into programme curricula and providing work-integrated learning to give life experiences. Such programs are expected to be able to increase students' employability and link university graduates with the users.

The program allowing students to have rights to study three semesters outside the study program in MBKM Policy, thus aims to enrich students' employability after they graduate from the HEIs. Having eight different types of learning, students at HEIs have freedom to choose any types of learning which can be done both within their own university and outside their institutions. Since this policy is relatively new in Indonesia, implementing MBKM Policy can be challenging for those who are involved in the process of education. However, this policy also offers opportunities for the HEIs. This phenomenon is interesting to study. In addition, as this policy is meant to enhance students' employability, it is also interesting to investigate its implementation, especially from Holmes' point of view about graduate employability; possession, position, and process [10]. The following section discusses about Holmes's concept of graduate employability seen from possession, position, and process.

\subsection{Graduate Employability: possession, position, and process}

Students who have completed their study in the HEIs are expected to be ready to apply their knowledge and skills in their real job field. In order to perform well in their workplace, students should possess adequate employability. Employability is defined as the 'knowledge, skills and attributes that graduates are expected to be able to demonstrate they have acquired in higher education' [23]. This notion of employability is relatively out of date; however, these skills are still relevant with the current demands of workplace. In addition, Boden and Nedeva (2010) as cited in Clarke [22] differentiate between graduate and non-graduate with the possession of skills which are able to increase the graduates' opportunity to be successful in their graduate employment. Thus, employability or 'graduateness' comprises a key elements consisting of reflective thinking (refers to higher order thinking abilities, including meta-cognitive thinking), scholarship ( refers to a set of knowledge, skills, and attitudes that is associated with research in practice.), moral citizenship (refers to the idea of students as global citizens, including and highlighting students' moral development) [24]. Finally, Holmes proposes graduate employability as possession; position; and process. These competing notions is shown in Figure 1 [22].

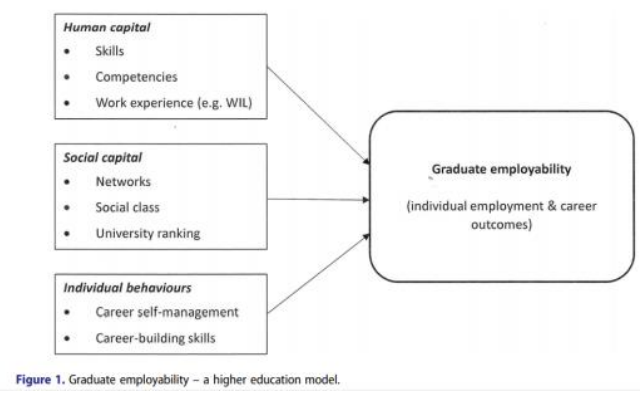

Figure 1. Graduate Employability - A Higher Eduction Model

Holmes [10] explains that graduate employability as possession is defined as a collection of achievements, comprising skills, knowledge and individual characteristics that make graduates more likely to be employed and effective in their chosen professions. Thus, students who have graduated from a university are expected to have knowledge related to their disciplines and skills which are useful in supporting their work in the 
future. In addition, students graduating from a university should possess personal attributes which enrich their qualities workers. Thus, graduate employability as possession is interpreted as the ability to have both hard skills and softs kills after students accomplished their study. Clarke [22] mentioned that in practice both hard skills such as discipline knowledge and soft skills such as communication, problem-solving, personal qualities, metacognition and team skills are considered in employment.

Holmes [10] stated that graduate employability as position refers to the influence of class and family background on employment outcomes. Students from wealthy family and good social class often have ample opportunities to study in a prestigious university. On the other hand, students from disadvantaged family and lower social class barely have options to choose a qualified and expensive university. Such condition often affects students' employment in that top companies often employ graduates from prestigious and high rank universities despite the fact that those who enter higher education and successfully leave as graduates are those who have 'succeeded' in education [22]. A study by Okay-Somerville and Scholarios (2015) as citied in Clarke [22] stated that there was a link between university rank and graduate employability. They noted that graduates of the less prestigious 'new' universities showed lower perceived external employability, possibly reflecting the different standard of students entering institutions of lower status.

The third view of graduate employability as process relates to the mechanism by which students transfer from HEIs to the workforce. Holmes [10] stated that students graduating from a university must build their skills and attributes acquired in gaining a degree, and therefore they start to build their graduate identity which they present to the employers. In this context, these graduates must show their graduateness [22] that differentiate them from other graduates or even from nongraduates, so that the employers have information which enables them to decide whether to be accepted or not in their companies. Thus, graduate identity is crucial, both for graduates and for future employers. Okay-Somerville and Scholarios as cited in Clarke [22] argued that career self-management and related activities such as career exploration, guidance seeking and networking are a crucial element in this process. Indeed, students are expected to have proactive career behaviors as they will determine the important factors in building and enhancing their employability [25].

\section{PREPARATION IN IMPLEMENTING MBKM}

The policy of MBKM which has been launched in February 2020 is relatively new in Indonesia. Having the main objective to facilitate students' learning which can enhance graduate employability, the policy of MBKM provides challenges to many universities in Indonesia, and therefore, implementing the policy should be prepared carefully. The following section attempts to explain the preparation in implementing MBKM policy from the lens of graduate employability as possession, position, and process [10].

\subsection{Possession}

In the previous section, it is explained that graduate employability as possession is defined as a collection of achievements, comprising skills, knowledge and individual characteristics that make graduates more likely to be employed and effective in their chosen professions. This way, graduate employability as possession can be interpreted as human capital. In order to produce qualified human capital, HEIs must equip students' hard skills and soft skills once they accomplished their study. In addition, to achieve these goals, the curriculum as the guidance of education institutions must be adjusted.

\subsubsection{Enhancing students' hard skills and soft skills}

Graduate employability becomes one of the indicators of HEIs' outcomes. In order to equip the students with competitiveness in global job market, the institutions must prepare them with both hard skills and soft skills. In terms of hard skills, the study programs in HEIs must give freedom to their students to take any of the eight activities during their three semesters such as 1) conducting internships / work practices in industry or other workplaces, 2) carrying out community service projects in villages, 3) teaching in education units, 4) participating in student exchanges, 5) conducting research, 6) conducting entrepreneurial activities, 7) making studies / independent projects, and 8) joining the humanitarian program [11]. In facilitating these activities, the study program must prepare several things, namely 1) preparing the students with sufficient information about the program they want to take, 2) preparing the teachers so that they can assist the students in doing the activities, 3) conducting cooperation and collaborations with many parties such as schools, companies, other universities, research institutions, local authorities, and so forth, 4) providing a startup business incubation center, and 5) preparing facilities for students to conduct their independent learning.

In facilitating students to have adequate soft skills which are needed in their work field, the study program can do several things, such as 1) providing subjects focusing on soft skills, 2) integrating soft skills in the core subjects, and 3) giving bridging courses. All of these activities must be considered seriously, and therefore 
adjusting the previous curriculum into the one oriented to MBKM policy is compulsory. This issue is discussed in the next section.

\subsubsection{Adjusting the Curriculum}

Curriculum is a guideline for universities to run teaching and learning process so that the graduates who are produced can meet the demands of job markets. Therefore, the curriculum should be directed to fit the needs of graduate users. With the MBKM policy, the curriculum should be adjusted, and this is not an easy job. All parties involved in the university must discuss and formulate a curriculum in accordance with the MBKM policy. In addition, the curriculum must also be able to accommodate students' freedom to get one semester of learning outside the study program within the university, and learning opportunities for a maximum of two semesters or the equivalent of 40 credits in other universities.

In adjusting the curriculum, the study program should prepare several activities, such as 1) finding equal credits for the eight programs offered in MBKM, 2) finding subject substitution to accommodate the eight programs offered in MBKM, and 3) reformulating the number of credit of core subjects, and 4) designing the system of subject exchanges among study programs within and outside university.

These activities must be executed in order to support students' learning. However, it takes time to arrive at full implementation, and therefore cooperation between all elements of education within the university must be carried out. In fact, The Minister of Education and Culture Rules or Permendikbud No 3 / year 2020 on national Standard of Higher Education indicates paradigm shifts in HEI's management systems.

\subsection{Position}

Graduate employability as position refers to the impact of social class on employment outcomes. In this context, students graduating from prestigious HEIs are assumed to obtain more benefits than those from low rank universities. Even though this case does not always happen, many employers or companies seek graduates of high rank universities. In responding to such situation, HEIs should always maintain their quality by conducting several activities such as establishing networking and collaboration and increasing university ranking. The followings explain these issues in more detail.

\subsubsection{Establishing (social) networking}

The policy of MBKM demand HEIs to build networking with many parties so that the implementation of the eight programs offered to students can run smoothly. Networking refers to building and maintaining relationships with other parties which may lead to a mutually beneficial exchange at some point in the future [26]. The activity of professional network will provide many opportunities for HEIs as establishing and building professional relationships is often maintained over a significant period of time. With the technological and information development, nowadays, many HEIs use Social Network Service (SNS) or social media to build networking and share information related to their institutions. However, despite many advantages the HEIs can obtain, the use of social media is potential to cause problems. Thus, anticipating the problems which may arise is advised.

Nowadays, it is commonly acknowledged that young people, including university students, cannot be separated from social media. They likely access information from social media everywhere and every time, including their university life. In fact, the use of social media is becoming popular among university students. Social networking sites have become a very important aspect in student's life. Myspace and Facebook as types of social media are used to communicate with others about school, professors, or courses [27]. However, the study conducted by Davila et.al [28] reported that social networking more likely to occur and more likely to include negative interactions and negative affect [28].

Using social networking, a university can share information related to education policies, teaching and learning process, documents, and lecturer, as well as students. The use of this social media can facilitate social interaction between the university and the students, the students and the other students, as well as the university and other parties. Interaction between the university is, however, potential to be misused by irresponsible others. In fact, people do not know how their personal data can be shared [29]

\subsubsection{Establishing collaborations}

The MBKM policy implies several collaborations which need careful preparation in its implementation and failing to do so can result in several problems. The first potential problem is that there is a gap between the quality of HEIs in Indonesia. Some HEI's belong to the top ranks, while some others are on the contrary. Thus, it is assumed that only universities with good quality can collaborate with each other [30]. Consequently, universities with low quality will be increasingly left behind and have difficulty building networks to develop knowledge in real-world applications or the world of work. Another problem that is likely be faced by HEIs include the possibility of difficulties in handling student administration who transfer from one study program to another, or even from one campus to another campus. Finally, the challenges are related to the differences in 
assessment standards between one university and another [30].

Being able to identify these problems becomes the important key to the success of MBKM implementation. In seeking the solutions to these problems, all stake holders in the HEIs must work together and responsible to their own roles and responsibility.

\subsubsection{Increasing university Ranking}

This implementation of MBKM policy demands HEIs to always improve their qualities in order to be able to compete with other universities. In order to do so, HEIs must synergize with various components, such as board of trustees, academic senate, board of professors, university work units, faculties, departments, study programs, lecturers, and each of which has different roles and functions.

In terms of internal level, HEIs must strengthen the Three Pillars of Higher Education (Tri Dharma Perguruan Tinggi) so that the performance of academic staffs in teaching, researching, and conducting community service can be done effectively. In addition, the HEIs must encourage their academic staffs to get international recognition by sending them to staff exchange program, visiting scholars, improving inbound students, and having international research collaborations as well as increasing the number of international publications. On the other hand, HEIs must start to apply for international accreditation in order to get acknowledgment from international institutions. This way, the university can improve their rank in the world which eventually results in students' better outcomes. As these are not an easy task, all of the elements of university must contribute significantly; otherwise they will be left behind.

\subsection{Process}

The third view of graduate employability as process relates to the mechanism by which students transfer from HEIs to the workforce. The success of graduate employability is greatly influenced by individual behaviors. In addition, individual behaviours are strongly associated with career self-management or 'career relevant behaviours [that] influence objective and subjective employability over and above social and educational backgrounds' [22]. She added that career management skills are divided into two categories - selfmanagement skills and career building skills. These skill will create students graduate identity which comprises how students perceive and present themselves, and how others see them [10]. What should HEIs prepare to support students' graduate identity is explained below.

\subsubsection{Career self-management}

Career self-management is related to personal awareness in terms of how individual can manage their emotion. Bradley and Ben [31] highlight the importance of emotional intelligent which cover five main areas: self-awareness, emotional control, self-motivation, empathy and relationship skills as important factors in determining future careers for students. They added, such skills developed in their formative years during study often provide the foundation for future habits later on in their life [31].

In an attempt to support graduates' intrapersonal skills, the study programs in HEIs must design their curriculum appropriately. Based on the Indonesian Higher Education curriculum, the students' learning outcomes are focused on hard skills and soft skills, and in this context. In addition, the curriculum has recommended Student Centred Learning (SCL) as the emphasis of teaching and learning process. Therefore, interpersonal skills can be delivered in several ways, such as integrating them into curricular and co-curricular in which students must participate in active learning. A study conducted by Connolly and Reinicke [32] showed that an active learning method is successful to increase students' soft skills and emotional intelligence in a project management classroom.

Based on the evidence collected in the classroom, this approach engaged the students in the learning process and improved interpersonal skills. This research presented ways to incorporate these skills into the curriculum without sacrificing quality. However, assessing students' interpersonal skills is not an easy task. Therefore, the study programs should provide clear rubrics and indicators so that all elements of the study programs can monitor the students' progress. Indeed, delivering tacit skills such as interpersonal skills cannot be done straightforwardly, therefore, students must be trained seriously since in the very beginning of their study.

\subsubsection{Career building skills}

While building interpersonal skills needed in the job field, students can start to build their career as early as possible. Career building skills help graduates manage and advance the in the world of job field. There are several activities that study programs can do to support students; building career, such as providing various elective courses which are relevant to graduate profiles. In addition, the study programs allow students to take courses or activities as recommended in the MBKM policy. Next, the study program should equip the lecturers with sufficient knowledge and training so that they can assist students and give advice related to activities that the students want to take. Finally, the study program join collaboration with other HEIs and companies to support students' internship. This way, students have opportunities to improve their skills directly from the users, and the link and match between 
the HEIs and the users can be established. In fact, this practice is Work Integrated Learning or WIL, and has been implemented in UK and Australia [33]. They added that beyond the UK, there is also a clear interest in WIL as a way of developing graduate employability which is often driven by similar agendas.

\section{CONCLUSION AND RECOMMENDATIONS}

The MBKM policy which is relatively new in Indonesia aims to improve graduate employability. Based on the Minister of Education and Culture Regulation, No. 3/2020 on National Standards of Higher Education, the MBKM policy should be implemented by all HEIs in Indonesia. In an attempt to prepare the implementation of MBKM policy, and based on the concept of graduate employability such as possession, position, and process, the HEIs must prepare various activities so that the MBKM policy can be implemented successfully.

\section{REFERENCES}

[1] J. Hartog and H. Oosterbeek, "Health, wealth and happiness: why pursue a higher education?", Economics of Education Review, 17(3), 245-256, 1998. Online, Available: https://www.sciencedirect.com/science/article/ abs/pii/S0272775797000642

[2] S. Wolla. A and J. Sullivan, Education, income, and wealth, Page One Economics Newsletter, Federal Reserve Bank of St. Louis, pages 1-1, January, 2017.

[3] B. P. Statistik, "Tingkat Pengangguran Terbuka (PTP) Sebesar 5, 50 Persen" dalam https://www. bps. go. id/pressrelease/2016/05/04/1231/februari2016--tingkat-pengangguran-terbuka--tpt-sebesar-5-50-persen, 2016.

[4] U. Okeke-Uzodike, "University as an Idea: For Qualifications or for Knowledge?” In J. E. a. A. Icha-Ituma (Ed.), Building Entrepreneurial Universities in a Developing Economy: Issues, Challenges and Prospects (First ed.): FUNAI Press., 2016.

[5] M. Kisworo, Undang-undang no. 12 tahun 2012 tentang Pendidikan Tinggi, 2012.

[6] M. I. Hossain, K. Yagamaran, T. Afrin, N. Limon, M. Nasiruzzaman, and A. Karim, "Factors influencing unemployment among fresh graduates: A case study in Klang Valley, Malaysia", International Journal of Academic
Research in Business and Social Sciences, 8(9), 1494-1507, 2018.

[7] O. Longe, "Graduate unemployment in Nigeria: causes, consequences and remediable approaches", American International Journal of Contemporary Research, 7(4), 63-73, 2017.

[8] V. Sam, "Unemployment duration and educational mismatches: An empirical investigation among graduates in Cambodia". Economics Bulletin, 38(3), 1554-1565, 2018.

[9] P. Knight, and M. Yorke, Learning, curriculum and employability in higher education: Psychology Press, 2004.

[10] L. Holmes, "Competing perspectives on graduate employability: possession, position or process?" Studies in higher education, 38(4), 538-554, 2013.

[11] Nizam, Panduan Merdeka Belajar - Kampus Merdeka. Jakarta, Indonesia: Direktorat Jenderal Pendidikan Tinggi Kemendikbud RI, 2020.

[12] E.H. Yohanes, "Ini Rangkuman 4 Kebijakan Kampus Merdeka Mendikbud Nadiem" Kompas, 25 January 2020.

[13] L. J. Putera, and R. Sugianto, "Perception and optimism about two semester off campus internship program of the Kampus Merdeka Merdeka Belajar (Freedom campus-Freedom to Learn) policy among university students". Journal of Languages and Language Teaching, 8(3), 264-275, 2020.

[14] S. Sharma and P. Dwivedi, "A Comparative Study of Existing Mechanisms for Implementation of OBE in Various Countries", Assessment Tools for Mapping Learning Outcomes With Learning Objectives (pp. 198210): IGI Global, 2020.

[15] S.A Farah and H. A. Ali, "A Study on the Causes of Unemployment among University Graduates in Kenya: A Case of Garissa County, Kenya", European Journal of Social Sciences Studies, 2018.

[16] P. Mncayi, "An analysis of the perceptions of graduate unemployment among graduates from a South African University", 2016.

[17] P. Mncayi and S.H. Dunga, "Career choice and unemployment length: A study of graduates from a South African university". Industry and Higher Education, 30(6), 413-423, 2016. 
[18] I.M. Muñoz García and J. González Monteagudo, "Perspectives of Non-Traditional University Graduates on Internships: Skills, Employability and Transition to the Labour Market in Spain”, 2020.

[19] V. Rudakov, H. Figueiredo, P. Teixeira, and S. Roshchin, "The impact of horizontal jobeducation mismatches on the earnings of recent university graduates in Russia”, 2019.

[20] L. Yang, "Higher education expansion and postcollege unemployment: Understanding the roles of fields of study in China". International Journal of Educational Development, 62, 62-74, 2018.

[21] Kemdikbud, "Mendikbud Luncurkan Empat Kebijakan Merdeka Belajar: Kampus Merdeka" [Press release], 2020. Retrieved from https://www.kemdikbud.go.id/

[22] M. Clarke, "Rethinking graduate employability: The role of capital, individual attributes and context", Studies in higher education, 43(11), 1923-1937, 2018.

[23] J. Hillage and E. Pollard, Employability: developing a framework for policy analysis (Vol. 107): DfEE London, 1998.

[24] J. Steur, E. Jansen, and A. Hofman, "Towards graduateness: exploring academic intellectual development in university master's students", Educational Research and Evaluation, 22(1-2), 6-22, 2016.

[25] M. Fugate and A.J. Kinicki, “A dispositional approach to employability: Development of a measure and test of implications for employee reactions to organizational change", Journal of Occupational and Organizational Psychology, 81(3), 503-527, 2008.

[26] B.R. Jennifer, R. John, and E. Samantha, "Should I be networking? Exploring the importance of networking for students", 2017. Retrieved from https://www.apa.org/ed/precollege/psn/2017/01 /importance-networking

[27] M.I. Eid and I.M. Al-Jabri, "Social networking, knowledge sharing, and student learning: The case of university students". Computers \& Education, 99, 14-27, 2016.

[28] J. Davila, R. Hershenberg, B.A. Feinstein, K. Gorman, V. Bhatia, and L. R. Starr, "Frequency and quality of social networking among young adults: Associations with depressive symptoms, rumination, and corumination". Psychology of popular media culture, 1(2), 72, 2012.

[29] A. Abdulahi, B. Samadi, B, and B. Gharleghi, "A study on the negative effects of social networking sites such as facebook among asia pacific university scholars in Malaysia", International Journal of Business and Social Science, 5(10), 2014.

[30] A.P. Wahyu, “100 Hari Nadiem Makarim: Catatan Kritis tentang Kebijakan Kampus Merdeka", Kompas, 2020

[31] B. Bradley and O. Ben, "Emotional intelligence: why it matters and how to teach it", 2017. Retrieved from https://www.theguardian.com/teachernetwork/2017/nov/03/emotional-intelligencewhy-it-matters-and-how-to-teach-it

[32] A. J. Connolly and B. Reinicke, :How to teach emotional intelligence skills. Information Systems Education Journal, 15(4), 4, 2017), 2017.

[33] A. McGrane, N. King, and V. Burr, "Work Integrated Learning and Development of Graduate Identity", Paper presented at the British Academy of Management, United Kingdom, 2019. 